\title{
Postharvest Losses of Tomato (Solanum Lycopersicum) in the Open Markets in Ibadan Metropolis
}

\author{
Ojimi, K. $\mathbf{O}^{1 \rtimes(D)}$ \\ Oyediran, W. O' \\ Salawu, M. B ${ }^{s}$ \\ Abiodun, $\mathbf{Y}^{4}$ \\ Alaka F. $\mathbf{A}^{5}$ \\ Otufale, G. $\mathbf{A}^{6}$ \\ Ojo, O. $\mathrm{M}^{7}$
}

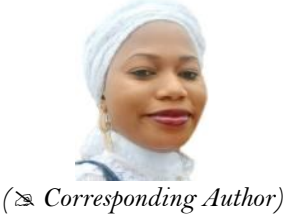

${ }^{1, s, 4}$ Department of Agricultural Extension and Management, Federal College of Animal Health and Production Technology, Moor Plantation, Ibadan, Nigeria.

'Email: ojimikafilatolaide@gmail.com

${ }^{2}$ Department of Agricultural Extension and Rural Development, Federal University of Agriculture, Abeokuta, Nigeria.

${ }^{5}$ Department of Agricultural Education, School of Secondary Education (Voc. \& Tech. Programmes), FCES, Oyo, Oyo State, Nigeria.

${ }^{6}$ Department of Agricultural Education, Tai Solarin College of Education, Omu-Ijebu, Ogun State, Nigeria. 'Department of Agricultural Extension and Rural Development, Ladoke Akintola University of Technology, Ogbomosho, Oyo State, Nigeria.

\section{Abstract}

Postharvest losses of tomato pose serious threat on the economic viability of actors in the tomato production chain in Nigeria. Therefore, postharvest losses of tomato among marketers in Ibadan Metropolis of Oyo State Nigeria were investigated by the researchers. One hundred and twenty tomato marketers were chosen from the five food markets in Ibadan metropolis through a simple random sampling technique. The study adopted linear regression and descriptive statistics to analyze data. The outcomes of the investigation show that females were $92.5 \%$ and $88.3 \%$ were married. Capital is primarily raised through cooperative societies $(57.5 \%)$. Postharvest losses of tomato accounted for $18.9 \%$ of purchase which represents $124,800 /$ day. The major causes of PHLs are poor packaging $(100 \%)$ and poor storage $(100 \%)$ by the tomato marketers. Meanwhile, all the respondents $(100 \%)$ adopted sorting to reduce PHLs of tomato. The regression analysis showed that education has a significant effect to reduce PHLs of tomato. The study concluded that huge postharvest and monetary losses of tomato are experienced by the tomato marketers. The study recommends provision of quality postharvest handling education to tomato marketers as a way of reducing PHLs of tomato in Ibadan.

Keywords: Tomato, Postharvest losses, Education, Food, Marketers, Metropolis, Packaging, Sorting, Storage, Ibadan.

Citation | Ojimi, K. O; Oyediran, W. O; Salawu, M. B; Abiodun, Y; Alaka F. A; Otufale, G. A; Ojo, O. M (2021). Postharvest Losses of Tomato (Solanum Lycopersicum) in the Open Markets in Ibadan Metropolis. Agriculture and Food Sciences Research, 8(2): 15-19.

\section{History:}

Received: 12 August 2021

Revised: 15 October 2021

Accepted: 10 November 2021

Published: 8 December 2021

Licensed: This work is licensed under a Creative Commons Attribution 3.0 License $(\mathrm{oc})$ )

Publisher: Asian Online Journal Publishing Group
Acknowledgement: All authors contributed to the conception and design of the study.

Funding: This study received no specific financial support.

Competing Interests: The authors declare that they have no conflict of interests.

Transparency: The authors confirm that the manuscript is an honest, accurate, and transparent account of the study was reported; that no vital features of the study have been omitted; and that any discrepancies from the study as planned have been explained.

Ethical: This study follows all ethical practices during writing.

\section{Contents}

1. Background of the Study 


\section{Contribution of this paper to the literature}

This paper contributes to the knowledge on postharvest losses because it looks at the dimension of tomato marketers in the city, unlike most previous studies that focus on rural areas. The study identified infrastructural deficit as a major setback to the proper handling of tomato hence, tomato PHLs are increasing while the income and profits of tomato marketers are seriously affected in the city.

\section{Background of the Study}

Agricultural losses are one of the greatest problems facing agricultural production in Nigeria. According to Oyediran and Omoare [1] PHLs regularly happen along the food supply chain, from the ranch door through till it gets on the table of the final consumer. Losses are experienced along the chain in the dealing with, capacity, transportation and preparing, in this way bringing about a decrease in the amount, quality and market worth of horticultural products [2]. The fundamental driver of PHLs incorporate mechanical harm, physiological decay and organic, that is, postharvest diseases and insect pests [3]. Rodents and birds additionally cause postharvest misfortunes in tomatoes [4]. Losses are because of unpleasant dealing with, helpless bundling and quality misfortunes brought about by temperature stress [5]. Additionally, the degree of misfortunes is essentially impacted by pre-collect conditions and field activities, for example, cultivar and soil types, crop the executives rehearses, helpless climate conditions, creepy crawly bug control projects and reaping just as bundling and dealing with rehearses [6]. Postharvest losses are predominant in fruit and vegetables among which is tomato crop. Postharvest losses of this crop ranges between $20-40 \%$ [7]. Tomato (Solanum lycopersicum) is highly perishable crops with attendant high postharvest losses. The bulkiness of tomato adds to transportation inconveniences and storage difficulty. However, it is perhaps the most mainstream and generally developed natural product on the planet including Africa [8]. It is local to South America [9]. The harvest was brought into West Africa by Portuguese brokers and liberated slaves from West Indies [10]. Tomato is developed and eaten from one side of the planet to the other. It is utilized differently, remembering crude for plates of mixed greens, and prepared into tomato soup. It is the second most significant vegetable around the world, as far as the measure of nutrients and minerals it adds to the eating routine [11]. Tomato is plentiful in nutrients, minerals and lycopene [12]. It is an amazing cell reinforcement that assists with lessening the danger of prostate and bosom malignant growth [13]. In Nigerian markets, tomato is sold fresh to the consumers. Many times, marketers particularly in the northern Nigeria preserved this crop by sun drying and sold in bags and baskets. In the southern Nigeria, the crop is usually grinded, boiled and put inside refrigerators or in jars. However, the marketing of tomato is influenced by various issues notwithstanding certain components of cultivating [14]. These incorporate the irregularity of creation, which subjects a country's creation to changes dependent on deficient water system offices. Losses likewise happen on the way because of significant distance to business sectors, poor and insufficient foundations, and the strategy for transportation of tomato [15]. It is against this foundation that this examination evaluated postharvest misfortunes of tomato among marketers in Ibadan Metropolis, Oyo State.

\subsection{Objective of the Examination}

The broad objective of this examination was to evaluate the postharvest losses of tomato among marketers in the investigation region.

\subsection{Explicit Goals}

The particular goals of the investigation were to;

i. Describe the financial attributes of the respondents in the investigation region.

ii. Estimate the worth of misfortune experienced by the tomato advertisers in the investigation region.

iii. Identify the significant reasons for postharvest misfortune in tomato advertising in the investigation region.

iv. Determine the financial variables impacting postharvest misfortunes of tomato in the examination region.

v. Assess the procedures took on by tomato dealers towards lessening postharvest misfortunes in the investigation region.

\section{Research Methods}

\subsection{Study Region}

The examination was done in Ibadan, a city in south western piece of Nigeria, capital of Oyo State, situated around $110 \mathrm{~km}$ (around $70 \mathrm{mi}$ ) upper east of Lagos. Ibadan is a significant travel point between the coast and regions toward the north. The number of inhabitants in Ibadan city region expanded at a development pace of $3.9 \%$ per annum from 1952 to 1963 when the populace rose to 1,258,625, then, at that point to 1,829,300 of every 1999 at a development pace of $1.65 \%$ from 1963 [16]. The populace development is said to have moved step by step to the lesser city with a development pace of $4.7 \%$ per annum somewhere in the range of 1991 and 2006. It exists in the scope 7oC 19' $08^{\prime \prime}$ and 7o $29^{\prime} 25^{\prime \prime}$ of the equator and longitude $3047^{\prime} 50^{\prime \prime}$ and $400^{\prime} 22^{\prime \prime}$.

\subsection{Sampling Procedure and Sample Size}

Purposive sampling technique was used for this study. Ibadan metropolis was purposively selected because of predominance of tomato markets in the city. Out of 9 major tomato markets in Ibadan, five (5) were randomly selected which are, Shasha, Bodija, Orita Merin, Oja Oba and Oje. Twenty-four were arbitrarily chosen from each market, making the complete number of 120 respondents for this investigation.

\subsection{Measurement of Variables and Data Analysis}

The estimates of tomato losses on daily basis was calculated by the differences between the total quantity $(\mathrm{kg})$ of tomato bought and quantity of tomato sold by the respondents, and multiplying it by the price per $\mathrm{kg}$ which is $\mathrm{N} 400.00$. The information was broke down utilizing both elucidating insights and direct relapse. 


\subsection{Respondents' Qualities}

Age distribution in Table 1 shows that $45 \%$ of the tomato marketers were 31 to 40 years, followed by $25.83 \%$ that were in age category 41 to 50 years, and just $9.17 \%$ were between $51-60$ years. The mean age was 38.44 years which implies the tomato sellers are in their productive age. Majority of the respondents are females, with $92.5 \%$, while the remaining $(7.5 \%)$ were male tomato sellers. Most $(88.3 \%)$ of the respondents were married while others were single $(7.5 \%)$, divorced $(3.3 \%)$ and widowed $(0.8 \%)$. The average household size of the respondents was 4- 6 members for $58.33 \%, 1-3$ members for $30.83 \%$ and more than 6 members for $10.83 \%$. Secondary occupation distribution reveals that $91.67 \%$ of the respondents did not engage in secondary occupation other than selling of tomato.

Table-1. Distribution of respondents by socio-characteristics $(n=120)$.

\begin{tabular}{|c|c|c|c|c|}
\hline Variables & Category & Frequency & Percentages & Mean \\
\hline \multirow[t]{4}{*}{ Age } & $<30$ & 24 & 20.00 & 38.44 \\
\hline & $31-40$ & 54 & 45.00 & \\
\hline & $41-50$ & 31 & 25.83 & \\
\hline & $51-60$ & 11 & 9.17 & \\
\hline \multirow[t]{2}{*}{ Sex } & Male & 9 & 7.50 & \\
\hline & Female & 111 & 92.50 & \\
\hline \multirow[t]{4}{*}{ Marital Status } & Single & 9 & 7.50 & \\
\hline & Married & 106 & 88.30 & \\
\hline & Divorce & 4 & 3.30 & \\
\hline & Widow & 1 & 0.80 & \\
\hline \multirow[t]{3}{*}{ Religion } & Islam & 70 & 58.30 & \\
\hline & Christianity & 49 & 40.80 & \\
\hline & Traditional & 1 & 0.80 & \\
\hline \multirow[t]{6}{*}{ Household size } & $1-3$ & 37 & 30.83 & 4.00 \\
\hline & $4-6$ & 70 & 58.33 & \\
\hline & $>6$ & 13 & 10.83 & \\
\hline & \multicolumn{2}{|c|}{ Secondary occupation } & & \\
\hline & Yes & 10 & 8.3 & \\
\hline & No & 110 & 91.67 & \\
\hline
\end{tabular}

\subsection{Sources of Credit and Accessibility by the Tomato Marketers}

As shown in Table 2, credit is marginally accessible by $45.8 \%$ of the respondents while $54.2 \%$ did not have access to credit. This reflects in the source of funds distribution which reveals that $57.5 \%$ of the respondents get credit from cooperative societies, and 30\% used money accrued from their personal savings. Access to credit by almost sixty percent of the respondents is due to the fact that majority $(73.3 \%)$ of the respondents were members of cooperative society. Average earning by the respondents was $\$ 55,575$ in which $45 \%$ of the respondents earned between $\$ 30,000$ to 40,000 . Fifty percent of the respondents had spent between $6-10$ years in the marketing of tomato while the average years of experience was 6.4 years.

Table-2. Distribution according to Sources of credit and accessibility by the tomato marketers ( $\mathrm{n}=120)$.

\begin{tabular}{|c|c|c|c|c|}
\hline Credit Sources & Category & Frequency & Percent & Mean \\
\hline \multicolumn{5}{|l|}{ Credit accessibility } \\
\hline & Yes & 55 & 45.80 & \\
\hline & No & 65 & 54.20 & \\
\hline \multirow[t]{3}{*}{ Source of fund } & Cooperative society & 69 & 57.50 & \\
\hline & Bank & 13 & 10.80 & \\
\hline & Personal savings & 36 & 30.00 & \\
\hline \multicolumn{5}{|c|}{ Membership of cooperative society } \\
\hline & Yes & 88 & 73.30 & \\
\hline & No & 28 & 23.30 & \\
\hline \multirow[t]{3}{*}{ Mode of earning income } & Daily & 108 & 90.00 & \\
\hline & Weekly & 7 & 5.80 & \\
\hline & Monthly & 3 & 2.50 & \\
\hline \multirow[t]{5}{*}{ Monthly earning $(\mathrm{N})$} & $<30,000$ & 14 & 11.67 & 55,575 \\
\hline & $30,001-50,000$ & 54 & 45.00 & \\
\hline & $50,001-70,000$ & 27 & 22.50 & \\
\hline & $70,001-90,000$ & 13 & 10.83 & \\
\hline & $90,001>$ & 12 & 10.00 & \\
\hline \multirow[t]{4}{*}{ Marketing experience (yrs.) } & & 6.39 & & \\
\hline & $<5$ & 55 & 45.83 & \\
\hline & $6-10$ & 60 & 50.00 & 6.4 \\
\hline & $11-15$ & 5 & 4.17 & \\
\hline
\end{tabular}

\subsection{Estimate of the Value of Loss Experienced by Tomato Marketers}

The results in Table 3 revealed that the estimated value of tomato purchased was $\$ 657,200.00$ while the quantity sold was $532,400.00$. The difference which is $124,800.00$ represented the tomato postharvest losses in the study area; these losses constitute $18.9 \%$ of total quantity tomato bought. 
Table-3. Average estimates of values of tomato losses daily basis by the marketers

\begin{tabular}{l|c|c|c}
\hline Tomato & Quantity loss $(\mathbf{k g})$ & Value (N) & \% \\
\hline Tomato bought & 1643 & $657,200.00$ & \\
\hline Tomato Sold & 1331 & $532,400.00$ & \\
\hline Tomato Loss & 312 & $124,800.00$ & 18.99 \\
\hline Note: Price per kg $=$ 4400.00. & &
\end{tabular}

Note: Price per $\mathrm{kg}=\mathrm{N} 400.00$

\subsection{Significant Reasons for Postharvest Misfortunes in Tomato Marketing.}

The significant reasons for misfortunes in tomato promoting are introduced in Table 4. The outcomes showed that poor packaging $(100 \%)$ and poor storage $(100 \%)$ of tomatoes are the two major causes of postharvest losses among tomato marketers. This implies that marketers need to be educated on how to best package and preserve tomato properly, as this may reduce tomato postharvest losses in the study area. It was also found that poor sanitation causes of postharvest losses by $99.2 \%$. This is followed by the problem of over-ripeness (98.3\%), poor handling (97.5\%), and tomato bruises (97.5\%). Results in Table 4 further revealed that $95 \%$ postharvest losses were caused by pathogen infestation while $91 \%$ of postharvest losses were due to bad roads during transportation of tomatoes from farm to market. However, $41.7 \%$ and $34.2 \%$ indicated that riot and limited alternative use of produce respectively were mild causes of postharvest losses.

Table-4. Causes of postharvest losses in tomato marketing $(n=120)$

\begin{tabular}{l|c|c|c}
\hline Major causes & \multicolumn{1}{|c|}{ Frequency (\%) } & Rank \\
\hline Poor packaging & Yes & No & \\
\hline Poor storage & $120(100)$ & $0(\%)$ & 1 \\
\hline Poor sanitation & $120(100)$ & $0(\%)$ & 1 \\
\hline Lack of processing unit & $119(99.2)$ & $1(0.8)$ & 4 \\
\hline Over ripeness & $118(98.3)$ & $1(0.8)$ & 4 \\
\hline Poor handling & $118(98.3)$ & $2(1.7)$ & 6 \\
\hline Bruises & $177(97.5)$ & $3(2.5)$ & 6 \\
\hline Pathogen infestation & $177(97.5)$ & $3(2.5)$ & 8 \\
\hline Bad roads & $114(95.0)$ & $6(5.0)$ & 9 \\
\hline Poor pre-harvest & $110(91.7)$ & $10(8.3)$ & 10 \\
\hline Bad state arrival at market & $99(82.5)$ & $21(17.5)$ & 1 \\
\hline Malformed fruit & $90(75.0)$ & $30(25.0)$ & 12 \\
\hline Non removal of field heat & $70(58.3)$ & $50(41.7)$ & 13 \\
\hline Drought & $59(49.2)$ & $61(50.8)$ & 14 \\
\hline Riot & $55(45.8)$ & $64(53.3)$ & 15 \\
\hline Limited alternative use of produce & $50(41.7)$ & $68(56.7)$ & 16 \\
\hline Soures Field Survey, & $41(34.2)$ & $79(65.8)$ & \\
\hline
\end{tabular}

Source: Field Survey, 2018.

\subsection{Techniques Adopted by Tomato Marketers towards Reducing Postharvest Losses}

The results indicated that proper sorting and grading (100\%) is the most adopted technique by tomato marketers to reduce amount of tomato postharvest losses (Table 5). This suggests that proper sorting and grading has been an effective technique adopted by the marketers to checkmate postharvest losses in the study area. Also, 95\%, 94.2\% and 92.5\% reported that proper packaging, proper handling, and transporting the tomatoes on a good road respectively reduce tomato postharvest losses. However, refrigerating (57.5\%) and covering of tomato with paper $(47.5 \%)$ were reported to be ineffective technique towards reducing tomato postharvest losses, and these are the least adopted techniques by tomato marketers.

Table-5. Techniques adopted by tomato marketers to reducing losses.

\begin{tabular}{l|c|c|c}
\hline Techniques & Frequency (\%) & Rank \\
\hline & Yes & No & \\
\hline Proper sorting \& grading & $120(100)$ & $0(0.00)$ & 1 \\
\hline Proper packaging & $114(95.0)$ & $6(5.0)$ & 2 \\
\hline Proper handling & $113(94.2)$ & $7(5.8)$ & 3 \\
\hline Good transportation & $111(92.5)$ & $9(7.5)$ & 4 \\
\hline Purchasing unripe tomatoes & $75(62.5)$ & $44(36.7)$ & 5 \\
\hline Refrigerator storage & $69(57.5)$ & $51(42.5)$ & 6 \\
\hline Covering tomato with paper & $57(47.5)$ & $63(52.5)$ & 7 \\
\hline Source: Field Survey, 2018. & & & \\
\hline
\end{tabular}

Source: Field Survey, 2018.

\subsection{Determination of the Factors Influencing Tomato PHLs}

Linear regression estimates of factors influencing PHLs of tomato are presented in Table 6 . The $\mathrm{R}$ is $79.8 \%$, which shows that there is high degree of correlation between the variables. The results further showed that only two variables in the model has a significant effect on value loss of tomato, and these are educational level and secondary occupation of the respondents. Though there is an inverse relationship between education level and value of tomato loss, that is, a unit increase in education level will reduce value of loss of tomato by $89.97 \%$. This shows that education can promote best ways to package and preserve tomato and it is a very vital factor that can reduce the value of tomato postharvest losses in the study area. Results in Table 6 also revealed engaging in a secondary occupation is significantly positive to value of tomato loss at $1 \%$. This indicates that there is a direct relationship between the two variables. This infers that, a unit increase in having secondary occupation will increase value of tomato losses by 55.86. This suggests that the more tomato marketers have a secondary occupation, the value losses of tomato experienced increase. Other variables, however, are found not significant to the tomato postharvest losses. 
Table-6. Factors affecting tomato misfortunes from the relapse gauges.

\begin{tabular}{l|c|c|c|c}
\hline Socio-economic factors & Coefficient & Std. Error & T & Sig. \\
\hline Constant & 997.425 & 279.226 & 3.572 & 0.001 \\
\hline Sex & 59.977 & 102.274 & 0.586 & 0.559 \\
\hline Age & 4.971 & 4.119 & 1.207 & 0.230 \\
\hline Educational status & $-89.974^{* * *}$ & 35.27 & -2.551 & 0.035 \\
\hline Household size & -47.465 & 39.619 & -1.198 & 0.233 \\
\hline Secondary occupation & $55.86^{* *}$ & 27.249 & 2.05 & 0.004 \\
\hline Marketing experience & -17.036 & 13.464 & -1.265 & 0.208 \\
\hline $\mathrm{R}=79.8 \% ;$ & & & & \\
\hline
\end{tabular}

Note: $* * * * 1$ percent sig., $* *$ percent sig.

\section{Conclusion}

This examination discovered that respondents are in their dynamic age and literates. But, they experienced high postharvest losses with attendant huge monetary losses on daily basis which is attributed to poor packaging and storage. Regression results showed that educational level of the respondents has inverse relationship but significant to the PHLs. The study therefore recommends that quality education on postharvest handling should be offered to the tomato marketers in order to reduce PHLs of tomato in the study area; electricity supply should be stable to encourage adoption of refrigeration in the tomato marketing; and government should construct good roads so as to ease the movement of the marketers and reduce tomato damages.

\section{References}

[1] W. O. Oyediran and A. M. Omoare, "Potentials and challenges of agricultural education in reducing postharvest losses and food insecurity in Ogun State, Nigeria," American Research Journal of Agricultural, pp. 1 - 10, 2016.Available at: https://doi.org/10.21694/2378-9018.16003.

[2] L. H. Aramyan and J. B. Gouh, "Reducing postharvest food losses in developing economies by using a Network of Excellence as an intervention tool," presented at the 2014 IFAMA and CCA Food and Agribusiness World Forum People Feed the World' in Cape Town, South Africa, June15-19, 2014.

[3] I. B. Adeoye, O. M. O. Odeleye, S. O. Babalola, and S. O. Afolayan, "Economic analysis of tomato losses in Ibadan Metropolis, Oyo State, Nigeria," African Journal of Basic \& Applied Sciences, vol. 1, pp. 87-92, 2009.

[4] Helvetas, "Consequences of post-harvest losses to vegetable farmers in Tanzania: A case of Singida region," HELVETAS Swiss Inter Cooperation Survey Report 2014, 2014.

[5] World Food Logistics Organization, "Identification of appropriate postharvest technologies for improving market access and incomes for small horticultural farmers in Sub-Saharan Africa and South Asia," WFLO Grant Final Report, University of California, UC, Davis, USA. 32010.

[6] Y. Kahsay, F. Abay, and D. Belew, "Intra row spacing effect on shelf life of onion varieties (Allium cepa L.) at Aksum, Northern Ethiopia," World Journal of Agricultural Research Food Safety, vol. 1, pp. 34-42, 2013.

[7] A. Kader, "Effects of postharvest handling procedures on tomato quality," presented at the Symposium on Tomato Production on Arid Land, 2003.

[8] G. N. Agrios, Plant pathology. New York, USA: Academic Press, 2003.

[9] O. Osemwegie, A. Oghenekaro, and L. Owolo, "Effects of pulverized Ganoderma spp., on Sclerotium rolfsii Sacc and post-harvest tomato (Lycopersicon esculentum Mill.) fruits preservation," Journal of Applied Sciences Research, vol. 6, pp. 1794-1800, 2010.

$[10] \quad$ E. Okwori and H. C. Dikko, "Tomato processing and utilization, Extension Bulletin. 241," 2010.

$[11] \quad$ E. C. Bombelli and E. R. Wright, "Tomato fruit quality conservation during post-harvest by application of potassium bicarbonate and its effect on Botrytis cinerea," Agricultural Science and Research, vol. 33, pp. 167-172, 2006.Available at: https://doi.org/10.7764/rcia.v33i3.346.

[12] D. John, R. T. Suthin, R. S. Usha, and R. Udhayakumar, "Role of defense enzymes activity in tomato as induced by Trichoderma virens against Fusarum wilt caused by Fusarium oxysporum F F. Sp Lycopersici," Journal of Biopesticide, vol. 3, pp. 158-162, 2010.

[13] E. Giovannucci, "Tomatoes, tomato-based products lycopene, and cancer: Review of the epidemiologic literature," Journal of the National Cancer Institute, vol. 91, pp. 317-331, 2000.Available at: https://doi.org/10.1093/jnci/91.4.317.

[14] V. O. Ebong, Agribusiness management in developing countries: The Nigeria perspective. Uyo: Dorand Publishers, 2000.

[15] D. Mukaminega, "Hybrid dryer (Solar and Biomass Furnace) to address the problem of post-Harvest losses of tomatoes in rwanda," Research Project Submitted to Larenstein University of Applied Sciences, Wageningen, The Netherlands, 2008.

[16] National Population Census (NPC), "National bureau of statistics official Gazette. (FGP 71/52007/2 500 (OL.24) Abuja. Retrieved from: http//www.nigerianstat.gov.ng," 2007. 